\title{
PEDAGOGIKA I PEDAGODZY Z MARGINESU WOBEC GŁÓWNEGO NURTU PEDAGOGIKI SOCJALISTYCZNEJ
}

\section{Pedagogy and educators from margin in the face of the main current of socialist pedagogy}

Summary: The author subjects the closer analysis of the situation of the pedagogy and her grows in Poland in the period of the Polish People's Republic (after the II World War), in which we happen certain group of pedagogues and educators who Robert Kwaśnica qualified as the „educators of the margin” next to the educators of the main current.

Characterizing the historical, and social, and ideological background of the exchanged period, the author seeks the answers on the question about the process of the maturation of the consciousness of illusions of the reformers of education and their experts, showing on propagandist enrolling this ideology in the pretenses of continuing the positivistic model of the production of scientific knowledge.

Near many, which became „enchanted and seduced” by socialist pedagogy, it did not lack these, which they be able to the masters of the period of their youth and the humanistic tradition of the pedagogy of the interwar period keep faithfulness.

Transformations what are started in Poland after 1989, they yielded the fruit the special shift to bring "educators from the margin" to the center of pedagogical thought (from outskirts) and yielded the fruit of the special intellectual, civil and moral obligation to participation in The Great Change.

Keywords: pedagogy, educators from the margin, socialist/communist pedagogy, humanistic pedagogy, ideology

1 Ks. prof. zw. dr hab. Marian Nowak - jest kierownikiem Katedry Pedagogiki Ogólnej na Wydziale Nauk Społecznych oraz dyrektorem Instytutu Pedagogiki w Katolickim Uniwersytecie Lubelskim Jana Pawła II w Lublinie. Adres: Al. Racławickie 14, 20-950 Lublin; e-mail: marian.nowak@kul.pl. 
Polska myśl pedagogiczna, aczkolwiek w historii jej rozwoju można wskazywać momenty bardziej odległe, wiąże się najwyraźniej z odzyskaniem niepodległości przez nasz kraj po ponadstuletniej nieobecności na mapach Europy. Niepodległe państwo stworzyło zatem podstawy instytucjonalne i gwarancje dla powstania i rozwoju pedagogiki. Możemy zatem i nawet powinniśmy świętować obecny rok 2018 - stulecie niepodległego państwa - jako rocznicę także istotną dla rozwoju polskiej myśli pedagogicznej².

Niedługo zresztą po tym fakcie - w 1919 roku - powstają pierwsze w niepodległej Polsce Katedry Pedagogiki: na Katolickim Uniwersytecie Lubelskim, wówczas jeszcze właściwie - Uniwersytecie Lubelskim, a jej kierownikiem zostaje przybyły z Krakowa, z UJ, prof. Zygmunt Kukulski (1890-1944), oraz na Uniwersytecie Poznańskim, a w siedem lat później na Uniwersytecie Jagiellońskim i Uniwersytecie Warszawskim³.

We wspomnianym stuleciu jest także bardzo specyficzny okres między wybuchem II wojny światowej a początkiem lat dziewięćdziesiątych ubiegłego wieku. Ten właśnie okres, dzielony jest niejednokrotnie na:

- I okres Bolesława Bieruta (1945-1956);

- II okres stalinizmu w Polsce i zarazem okres Władysława Gomułki (1956-1970);

- III okres Edwarda Gierka (1970-1980) - tzw. okres spokoju i radości;

- IV okres Wojciecha Jaruzelskiego (1980-1989) - a w nim m.in. stan wojenny.

Pierwsze trzy z tych okresów poddaję bliższej analizie, celem wydobycia i ukazania uwarunkowań działalności pedagogicznej pewnej tylko grupy pedagogów, których analogicznie do żołnierzy wyklętych można uważać za innych, odmiennych od głównego i oficjalnego nurtu ówczesnej polskiej myśli pedagogicznej. Za Robertem Kwaśnicą nazywam tych pedagogów „pedagogami marginesu”4 i to ich sytuacji chcę poświęcić szczególną uwagę.

To określenie rozszerzam na wszystkie osoby i środowiska, które w opisanych uwarunkowaniach miały odwagę i determinację realizowania pedagogiki i bycia pedagogami z marginesu, a faktycznie przy marginalizującej się do ideologii i praktyki pedagogiki instrumentalnej - w istocie to właśnie oni stanowili główny

2 Zob. Teresa Hejnicka-Bezwińska, W poszukiwaniu tożsamości pedagogiki. Świadomość teoretyczno-metodologiczna wspótczesnej pedagogiki polskiej (Geneza i stan) (Bydgoszcz: Wyższa Szkoła Pedagogiczna 1989), 130.

3 Zob. Jan Draus, Ryszad Terlecki, Historia wychowania, t. 2: Wiek XIX i XX (Kraków: Wydawnictwo WAM - WSFP „Ignatianum” 2005), 291.

4 Robert Kwaśnica w odniesieniu zwłaszcza do seminarium naukowego, które w Stacji Badawczej Instytutu Wsi i Rolnictwa w Toruniu prowadził prof. Zbigniew Kwieciński, opisał tam skupionych pedagogów jako „pedagogów z marginesu”. (Zob. Robert Kwaśnica, „O dwóch wersjach pytania o przedrozumienie. Do pedagogiki naukowej i pedagogów z marginesu”, w: Pytanie - dialog - wychowanie, red. Joanna Rutkowiak (Warszawa, Wydawnictwo Naukowe PWN 1992, 82-154). 
nurt uprawiania pedagogiki jako nauki. Przykładem konkretnym takiego właśnie stanu rzeczy może być popularność także w obecnej jeszcze dydaktyce akademickiej podręcznika Podstawy wspótczesnej pedagogiki Stefana Kunowskiego i nowe wydania jego prac.

\section{Dzieje pedagogiki i pedagogii w okresie Polskiej Rzeczypospolitej Ludowej - „socjalistycznej”}

Te początki można scharakteryzować jako szczególnie złączone z tradycją humanistyczną - swoistą chlubą II Rzeczpospolitej. Była ona budowana zresztą przez szerszą - niż tylko pedagogiczną - grupę takich profesorów, jak m.in.: Zygmunt Mysłakowski, Bogdan Nawroczyński, Kazimierz Sośnicki, Józef Chałasiński, Sergiusz Hessen, Aleksander Kamiński, Antonina Kłoskowska, Tadeusz Kotarbiński, Karol Kotłowski, Helena Radlińska, Jan Szczepański czy wspomniany już wyżej Zygmunt Kukulski, o. Jacek Woroniecki i wielu innych ${ }^{5}$.

Ta tradycja w pedagogice nawiązywała wyraźnie do Wilhelma Diltheya (1848-1911), twórcy metodologii nauk humanistycznych (grupy nauk uwzględniających sferę duchową człowieka i interpretujących jego działanie, w odróżnieniu od nauk wyjaśniających - przyrodniczych). Już w okresie międzywojennym zaznaczały się wprawdzie także inne orientacje w pedagogice, zwłaszcza te związane z perspektywą socjologiczną i psychologiczną, a nawet biomedyczną, ale właśnie tradycja humanistyczna, podnosząc prawa osoby ludzkiej, nie tylko je równoważyła, ale nawet te inne czyniła raczej marginalnymi ${ }^{6}$.

Tradycja humanistyczna $\mathrm{w}$ pedagogice $\mathrm{w}$ Polsce była wydatnie wspierana przez orientacje światopoglądowe i religijne, które z takim podejściem się utożsamiały, współdziałały lub też usiłowały je dopełniać. W przeważającej większości te inspiracje były związane z katolicyzmem i opierały się na założeniach personalizmu chrześcijańskiego Jacquesa Maritaina oraz na tradycyjnych założeniach teologicznych zawartych w tomizmie. Znaczący wpływ na rozwój tych orientacji miały dzieła Friedricha W. Foerstera: Szkoła i charakter (1909); O wychowaniu obywatelskim (1919); Wychowanie i samowychowanie (1920), zaś wytyczne dla tej orientacji widziano w encyklice Piusa XI: O chrześcijańskim wychowaniu młodzieży (Divini Illius Magistri, z 31 XII 1929). Powstało szereg prac, których autorami byli m.in.: o. Jacek Woroniecki (1878-1952), ks. Walenty Gadowski,

5 Zob. Hejnicka-Bezwińska, W poszukiwaniu tożsamości pedagogiki, 136-138; także Adam Orczyk (ks.), Zarys historii szkolnictwa i myśli pedagogicznej (Warszawa: Wydawnictwo Akademickie „Żak” 2008), 291-299.

6 Stefan Kunowski, „Polscy teoretycy wychowania”, w: Wkład Polaków do kultury świata, red. Mieczysław A. Krąpiec, Piotr Taras, Jan Turowski (Lublin: Towarzystwo Naukowe KUL 1976), 243-256. 
ks. Zygmunt Bielawski, ks. Karol Mazurkiewicz (Wychowanie w świetle chrześcijańskiej prawdy, 1938), ks. Wincenty Granat, Karol Górski (autor książki: Wychowanie personalistyczne $)^{7}$.

Swoistym ukoronowaniem tych dokonań $\mathrm{w}$ ramach orientacji religijnej był Zjazd Pedagogów Katolickich w 1937 roku, którego efektem stała się publikacja wydana jako pamiętniki zjazdu pt. Katolicka myśl wychowawczå. Wskazuję na wyżej wymienionych profesorów i eksponuję tradycję humanistyczną oraz religijną, aby tym bardziej wyeksponować ten dysonans, jaki mogło wywołać i faktycznie wywołało jej zderzenie się najpierw z ideologiami wychowawczymi narodowego socjalizmu niemieckiego, a następnie $\mathrm{z}$ ideologią komunistyczną. Zderzenie to - i to trzeba też stwierdzić - nie tyle intelektualne czy koncepcyjne, lecz siłowe, zaznaczyło się przydzieleniem pedagogice i pedagogom określonego, całkowicie innego, niż to było w ogóle rozważane - miejsca, jak też w strategiach wcielania pedagogiki i pedagogów w nowy tok myślenia o wychowaniu w naszej Ojczyźnie9.

Takie zderzenie $\mathrm{z}$ nowymi ideologiami było też odpowiednio przygotowane przez działania wojenne i egzekucje grup intelektualistów, a nawet cywilnej ludności i było poprzedzone osłabieniem grona profesorskiego - śmiercią (jak się oblicza) ponad 50\% samodzielnych pracowników nauki w Polsce, w tym także pedagogów. Zabrakło m.in.: Stefana Rudniańskiego, Stefanii Sempołowskiej, Władysława Spasowskiego, Janusza Korczaka. Po wojnie podejmują swoją działalność: Helena Radlińska, Aleksander Kamiński, Sergiusz Hessen, Bogdan Nawroczyński, Józef Chałasiński, Bogdan Suchodolski, także Stefan Kunowski i o. Jacek Woroniecki. W pierwszym okresie w latach 1944-1947 polska myśl pedagogiczna była jeszcze kontynuacją tradycji oraz kierunków z okresu II Rzeczypospolitej, można jedynie mówić o uaktywnieniu się i rosnącym uprzywilejowaniu lewicy, komunistycznych koncepcji wychowania i przenoszeniu doświadczeń edukacyjnych ze Związku Sowieckiego (ZSRR). Ten stan trwał jednak krótko. Objęcie Polski żelazną kurtyną i kontrolą komunistycznej bezpieki zmieniło na wiele dziesięcioleci sytuację uprawiania nauki w Polsce ${ }^{10}$.

Kończące się działania wojenne i powrót wojskowych do życia cywilnego wniosły nasycenie go $w$ ramach tzw. nowomowy, pojęciami o charakterze militarnym: „walka ideologiczna”, „front ideowy”, „ofensywa ideologiczna”,

7 Karol Górski, Wychowanie personalistyczne (Poznań: Drukarnia Diecezjalna we Włocławku 1936).

8 Katolicka myśl wychowawcza. Pamiętnik II. Studium Katolickiego w Wilnie w dniach 28 VIII 1 IX 1936 r., w serii Studia Katolickie, red. ks. dr Stanisław Bross (Poznań: Nakładem Naczelnego Instytutu Akcji Katolickiej 1937).

9 Zob. Orczyk Zarys historii szkolnictwa i myśli pedagogicznej, 299-311.

10 Zob. Hejnicka-Bezwińska, W poszukiwaniu tożsamości pedagogiki, 136-139; zob. także: Ryszard Wroczyński, Dzieje oświaty polskiej 1795-1945 (Warszawa: Wydawnictwo „Żak” 1996), 306-308; szerzej: Historia wychowania. Wiek XX, t. I-II, red. Józef Miąso (Warszawa: Państwowe Wydawnictwo Naukowe 1981). 
„rewizjonizm” itd. Biuro Polityczne Komitetu Centralnego Polskiej Partii Robotniczej (PPR) uchwaliło rezolucję o podjęciu „ofensywy ideologicznej wśród nauczycielstwa przeciw wrogiej ideologii, jego izolacji i negacji, o wciągnięciu do ofensywy ideologicznej wszystkich członków partii, członków innych partii i uczciwych demokratów bezpartyjnych, przez stałą współpracę w komisjach porozumiewawczych" ${ }^{11}$. Od pedagogiki i od pedagogów oczekiwano, że włączą się aktywnie w nurt „ofensywy ideologicznej” ${ }^{12}$. Ponieważ jednak pracownicy nauki (większość z nich) rozpoczynali pracę jeszcze w II Rzeczypospolitej i byli wpisani wyraźnie we wspomnianą tradycję humanistyczną, zwłaszcza z racji, że wielu odbywało studia w uczelniach Zachodniej Europy, tam uzyskując swoje stopnie naukowe i pozostając w ciągłej łączności z tą linią, nie śpieszyli się do tej ofensywy ${ }^{13}$.

Ta opieszałość pedagogów sprawiła też, że aktyw partyjny chciał pozyskać dla swojej ofensywy przynajmniej młodszych pracowników naukowych, świeżo wypromowanych magistrów czy doktorów, dla których zorganizowano Zjazd Naukowego Towarzystwa Pedagogicznego w 1948 roku. Ale i ten Zjazd nie przyniósł oczekiwanych przez partyjny beton rezultatów.

Wyrażono zatem nieufność wobec przedstawicieli nauk pedagogicznych, ograniczono nabór na studia w zakresie pedagogiki, a potem całkowicie je zlikwidowano we wszystkich uniwersytetach. Podobny los spotkał wkrótce także psychologię, filozofię i socjologię ${ }^{14}$.

Ministerstwo Oświaty państwa komunistycznego, nie mogąc liczyć na pomoc naukowców w „ofensywie ideologicznej”, dokonało samodzielnie „wielkiego i epokowego przełomu w oświacie", nazywanego I przełomowym krokiem, mając do dyspozycji jedynie aktyw PPR. Odrzucono teoretyczne rozważania jako drobnomieszczańskie i pochodzące od ciemnych sił kołtuństwa, a zwrócono się do praktyków, do nauczycieli.

W maju 1948 roku zorganizowano zjazd delegatów Związku Nauczycielstwa Polskiego w Poznaniu. Do delegatów przemawiał m.in. Józef Cyrankiewicz, kierując do nich słowa: „Wy formujecie to, co mamy najcenniejszego - umysły i poglądy młodzieży. W tej najtrudniejszej i najbardziej odpowiedzialnej pracy możecie zawsze liczyć na pomoc, poparcie i sympatię całego społeczeństwa i na pełne zrozumienie ze strony Rządu Rzeczypospolitej”'15.

Ofensywa ideologiczna wśród nauczycieli była dość skuteczna. W 1948 roku do Związku Nauczycielstwa Polskiego, z którego fatycznie usiłowano uczynić delegaturę lub przybudówkę PZPR, należało już 75000 nauczycieli, a z tego 21000 bezpośrednio jeszcze do partii komunistycznej i do innych stronnictw.

11 Zob. Teresa Hejnicka-Bezwińska, Praktyka edukacyjna $w$ warunkach zmiany kulturowej (Warszawa: Wydawnictwo Naukowe PWN 2015), 186.

12 Tamże, $186 \mathrm{nn}$.

13 Zob. taż, W poszukiwaniu tożsamości pedagogiki, 140nn.

14 Zob. tamże.

15 Zob. tamże, 141. 
Realizacji tych zadań dopomagały kryteria awansu oraz zasady selekcji do zawodu nauczycielskiego, a także zmiany w programach nauczania i związane z tymi zmianami liczne szkolenia i dokształcania ${ }^{16}$.

Dla wyróżniających się pod względem partyjniactwa nauczycieli szkół podstawowych organizowano 5-miesięczne kursy przysposobienia zawodowego i stawali się oni profesorami szkół średnich. Podobnie organizowano 5-miesięczne kursy dla kandydatów pochodzenia chłopskiego i robotniczego, którzy ukończyli 18. rok życia i co najmniej 7 klas szkoły podstawowej w tzw. RKKN - Rejonowych Komisjach Kształcenia Nauczycieli (funkcjonowały one zwłaszcza w latach 1951-1954) ${ }^{17}$.

Przystąpiono także do tzw. krytycznego obrachunku z pedagogicznym dziedzictwem przeszłości. Z takim krytycznym obrachunkiem wystąpili m.in.: Bogdan Suchodolski, Kazimierz Wojciechowski, Henryk Jabłoński. Krytycznie oceniono dotychczasowy dorobek polskiej myśli pedagogicznej i nakazano przystąpienie do tłumaczenia podręczników pedagogiki napisanych przez autorów radzieckich. Do polskich bibliotek i treści nauczania wchodzą nazwiska i poglądy: Iwana Kairowa, Borisa Tiepłowa, Nadieżdy Gonczarowej, Nadieżdy Krupskiej, Antona S. Makarenki ${ }^{18}$.

Młodym polskim pedagogom proponowano studia w Związku Radzieckim. Nawiązywano do zadań oświaty przedstawionych w 1919 roku przez Włodzimierza Lenina, który mówił, że „szkoła powinna być nie tylko transmisją zasad komunizmu w ogóle, lecz także transmisją ideologicznego, organizacyjnego i wychowawczego wpływu proletariatu na warstwy proletariackie i nieproletariackie, wpływu mas pracujących w celu całkowitego zgniecenia oporu wyzyskiwaczy i wprowadzenia ustroju komunistycznego" ${ }^{19}$.

Jak stwierdzał prof. Wincenty Okoń, pedagogika była wypaczana w dwu kierunkach, schodziła do ideologii, albo tylko do problemów praktycznych - stawała się po prostu socjalistyczną pedagogiką instrumentalną, a linię jej rozwoju wyznaczały dwa ekstrema: ideologia i praktyka - na tym polegała instrumentalizacja pedagogiki ${ }^{20}$. Brak zaufania wobec przedstawicieli pedagogiki miał swoje także bardzo głębokie konsekwencje dotyczące prestiżu pedagogiki jako nauki, a mianowicie pedagogiki $\mathrm{w}$ okresie powojennym nie było w strukturach Polskiej Akademii Nauk, natomiast przejawem umocnienia się tego stanowiska było utworzenie w niej w 1953 roku Komitetu Nauk

16 Zob. taż, Praktyka edukacyjna $w$ warunkach zmiany kulturowej, 176nn.

17 Zob. taż, W poszukiwaniu tożsamości pedagogiki, 143.

18 Zob. tamże, 147; zob. także Draus, Terlecki, Historia wychowania, t. 2: Wiek XIX i XX, $302 \mathrm{nn}$.

19 Cytowane za: Historia wychowania. Wiek XX, t. II, red. Miąso, 15.

20 Teresa Hejnicka-Bezwińska, „Paradygmat pedagogiki instrumentalnej w Polsce (Skutki jego dominowania w badaniach pedagogicznych i kształceniu pedagogów)", w: Ku pedagogii pograni$c z a$, red. Zbigniew Kwieciński, Lech Witkowski (Toruń: Uniwersytet Mikołaja Kopernika 1990), $158-175$. 
Pedagogicznych, którego przewodniczącym został Bogdan Suchodolski. Wyrażono też wkrótce zgodę na otwarcie Wydziału Pedagogiki na Uniwersytecie Warszawskim i Toruńskim.

Sytuacja stała się ponownie trudna w związku z wydarzeniami marcowymi w 1968 roku i tzw. protestem studentów, na który reakcją był tzw. II przełomowy krok związany z usunięciem wielu pracowników naukowych i studentów z Uczelni ${ }^{21}$. Miało to swój szerszy kontekst i reperkusje, których wyrazem było usankcjonowanie w Polsce na V Zjeździe PZPR w listopadzie 1969 konieczności dokonywania wymiany politycznej i wymiany pokoleniowej w kręgach władzy. Leonid Breżniew, jako gość tego Zjazdu - już po wydarzeniach w Czechosłowacji - przedstawił nową doktrynę „ograniczonej suwerenności” państw obozu socjalistycznego.

W Polsce oznaczało to, że do sprawowania władzy i obejmowania stanowisk doszło nowe pokolenie ludzi, nazwane „pokoleniem ZMP”, promujące „socjalizm menadżerski”, „socjalizm z ludzką twarzą", a więc nastawione na modernizację i pragmatyczne przystosowanie się do warunków i sytuacji bieżącej ${ }^{22}$.

Prof. Zbigniew Kwieciński tak pisał o tej wymianie pokoleniowej:

[...] w latach siedemdziesiątych zaczął się exodus z czynnego życia akademickiego uczonych o gruntownym przygotowaniu filozoficznym i metodologicznym, pokolenia świadomego dotychczasowej ewolucji i potrzeb pedagogiki na tle historii całej niepodległej Polski, pokolenia, dla którego identyfikacja z socjalistycznymi ideami humanizmu była tym głębsza, że dochodziło do niej po trudach niejakich albo po długiej o te ideały walce. Kto wchodził na miejsce tego pokolenia „sprawiedliwych”, oprócz świeżo wykształconych absolwentów, adeptów?

Do kierownictw mnóstwa instytutów i zakładów pedagogiki weszły dwa pokolenia ludzi: „ludzi organizacji” oraz ludzi o orientacji na karierę, awans, status, władzę. Wspólną ich cechą było późne i pośrednie dojście do pedagogiki z dwóch rzutów: powojennych działaczy i organizatorów oraz pośród działaczy bojowego pokolenia ZMP. [...] pokolenie zwycięzców w tej wojnie nie potrafiło wyzbyć się tego, co było jednym $\mathrm{z}$ jej istotnych znamion: totalitarnego myślenia. Tego też wyzbyły się nie wszystkie dzieci wojny ${ }^{23}$.

Wymianę pokoleniową w uniwersytetach wspierała reforma strukturalna. Nowe podstawy prawne stworzyła Ustawa o szkolnictwie wyższym przyjęta w 1968 roku, a wydana drukiem w 1969 roku. Na jej mocy zostały zlikwidowane w uniwersytetach katedry pedagogiki (wyjątkiem był Uniwersytet Mikołaja Kopernika); na ich miejsce powstały instytuty, którymi kierowały już zupełnie inne osoby.

${ }_{21}$ Zob. Hejnicka-Bezwińska, W poszukiwaniu tożsamości pedagogiki, 155nn.

22 Zob. tamże, 159nn; zob. także teksty referatów Czesława Kupisiewicza, Jerzego Kuberskiego, Czesława Banacha zamieszczone w Kwartalniku Pedagogicznym, 2 (1974).

${ }_{23}$ Zbigniew Kwieciński, Konieczność - niepokój - nadzieja. Problemy oświaty w latach siedemdziesiątych (Warszawa: Ludowa Spółdzielnia Wydawnicza 1982), 226-227. 
Wyrazem zaangażowania w zmianę pokolenia, które przejęło władzę w państwie i w nauce był tzw. II I przeło m owy krok związany z oświatą w 1976 roku, któremu towarzyszyły: VI Zjazd PZPR, II Kongres Nauki Polskiej pod patronatem I sekretarza PZPR Edwarda Gierka (1973), Partyjna Narada Pedagogów (1973) i II konferencja Pedagogów Krajów Socjalistycznych (1975) ${ }^{24}$.

Takie gremia nakreślały zadania i kształt pedagogiki na lata siedemdziesiąte $\mathrm{XX}$ wieku, a rezultatem ich działania była reforma edukacji wiązana $\mathrm{z}$ osobą ówczesnego ministra Jerzego Kuberskiego. Obradom tych ostatnich gremiów towarzyszył wprawdzie optymizm, nawet co do przezwyciężenia rzekomo fałszywej alternatywy: albo ideologia, albo praktyka, ale to potwierdzało jedynie tę instrumentalność i płytkość myślenia, którą jeden z nestorów polskiej myśli pedagogicznej konstatował stwierdzeniem: „po prostu zabrakło mistrzów”25.

Naniesiono wreszcie poprawki do Konstytucji (1976) wprowadzone w formie zapisu o:

1) przyjaźni i współpracy z ZSRR;

2) PZPR jako przewodniej sile politycznej społeczeństwa w budowie socjalizmu' ${ }^{26}$.

W ten kontekst dobrze wpisywały się działania reformowania oświaty z wykorzystaniem zbliżającej się rocznicy 200-lecia Komisji Edukacji Narodowej. W tym celu powołano z inicjatywy Biura Politycznego KC PZPR - Komitet Ekspertów, pod przewodnictwem Jana Szczepańskiego, do przygotowania Raportu o stanie oświaty w $P R L$, jednocześnie powołano zespół ministerialny do przygotowania reformy oświaty, pracujący równolegle i nie jest trudno zgadnąć, którego zespołu ustalenia miały moc decyzyjną.

Przekształcono Ministerstwo Oświaty w Ministerstwo Oświaty i Wychowania (z położeniem nacisku na „wychowanie” rozumiane jako indoktrynacja); przekształcono Instytut Pedagogiki w Instytut Badań Pedagogicznych (IBP) oraz powołano cztery nowe instytuty bezpośrednio podległe MOiW:

- Instytut Programów Szkolnych;

- Instytut Kształcenia Nauczycieli;

- Instytut Kształcenia Zawodowego;

- Instytut Badań nad Młodzieżąą.

24 Zob. tamże; zob. także Draus, Terlecki, Historia wychowania, t. 2: Wiek XIX i XX, 309nn; Zob. także Hejnicka-Bezwińska, Praktyka edukacyjna w warunkach zmiany kulturowej, 300nn.

25 Zob. Wincenty Okoń, „Sytuacja i perspektywy rozwoju pedagogiki w Polsce Ludowej, w: Stan i perspektywy rozwoju nauk pedagogicznych", red. Wincenty Okoń (Warszawa: Państwowe Wydawnictwo Naukowe 1976), 35-39.

26 Zob. Orczyk, Zarys historii szkolnictwa i myśli pedagogicznej, 311-313.

27 Jan Szczepański, w latach 1970-1973 był przewodniczącym Komisji Ekspertów do Przygotowania Raportu o Stanie Oświaty w Polsce, w latach 1977-1982 był też członkiem Rady Państwa. Efektem pracy Komitetu Ekspertów dla Opracowania Raportu o Stanie Oświaty w PRL jest: Raport o stanie oświaty w PRL (Warszawa: Państwowe Wydawnictwo Naukowe 1973). 
Dane te pokazują wyraźnie, że badania pedagogiczne zostały „wyprowadzone” z uniwersytetów i stały się domeną instytutów, podległych ministrowi (członkowi rządu, a nie korporacji uczonych). Najbardziej rozbudowane i najlepiej finansowane były badania w instytutach resortowych MOiW.

W uniwersytetach i szkołach wyższych zawodowych (kształcących nauczycieli) były one zredukowane raczej do badań służących celom awansowym, związanym z koniecznością uzyskiwania stopni i tytułów naukowych.

Kluczowym problemem związanym z projektowaną reformą systemu oświatowego, której celem miało być wprowadzenie tzw. dziesięciolatki, było kształcenie nauczycieli. Tylko $15,8 \%$ nauczycieli posiadało pełne wykształcenie wyższe (tytuł magistra) i 3,5\% wyższe wykształcenie zawodowe, resztę stanowili absolwenci liceów pedagogicznych i osoby bez stosownych kwalifikacji zawodowych.

Ustawa z dnia 27 kwietnia 1972 roku, nazwana Karta praw i obowiązków nauczyciela, zobowiązywała nauczycieli do ukończenia studiów (kobiety do lat 35 i mężczyzn do lat 40). Starsi nauczyciele mogli uzyskiwać w sposób eksternistyczny kwalifikacje równoważne z ukończeniem studiów zawodowych w zakresie nauczania początkowego lub w zakresie jednego z przedmiotów kształcenia systematycznego w klasach wyższych. Wprowadzenie tego obowiązku oznaczało konieczność dalszego dokształcania się ponad $80 \%$ czynnych zawodowo nauczycieli ${ }^{28}$.

W praktyce duża grupa nauczycieli uzyskała podwyższenie stopnia kwalifikacji przez ukończenie WUML-u (Wojewódzkiego Uniwersytetu Marksizmu-Leninizmu), a młodsi zostali włączeni w system nieustannego podnoszenia swoich kwalifikacji ${ }^{29}$. Masowe dokształcanie nauczycieli trwało przez lata i było realizowane głównie w nowo powstałych Wyższych Szkołach Pedagogicznych, w formie studiów zaocznych i eksternistycznych ${ }^{30}$.

Nie można nazwać tego inaczej niż tworzeniem kolejnych artefaktów w realnym socjalizmie, realizującym ontologiczną zasadę pozoru. WSP powstawały w miastach, które po reformie administracyjnej (wyodrębnienia 49 województw) stały się miastami wojewódzkimi - a więc w miastach bez tradycji akademickich ${ }^{31}$.

Przełomowym momentem w rozwoju polskiej pedagogiki - po odcięciu się od pedagogiki tradycyjnej (nazwanej „burżuazyjną”) było uznanie naukowego charakteru pedagogiki socjalistycznej. Przełom w polskiej pedagogice nie był aktem jednorazowym, lecz był procesem trwającym wiele lat. Odwołując się

28 Takie dane podaje Irena Wojnar, Bogdan Suchodolski, w: Myśliciele o wychowaniu, t. 2, (Warszawa: Polska Oficyna Wydawnicza BGW 2001), 394.

${ }^{29}$ Komitet Ekspertów dla Opracowania Raportu o Stanie Oświaty w PRL, red. Jan Szczepański (Warszawa 1973), 395.

30 O warunkach i kosztach takiego kształcenia mówią pamiętniki nauczycieli. O związkowym doskonaleniu nauczycieli z kolei mówi praca Edyty Kahl, Związkowe doskonalenie nauczycieli w Polsce (1944-1989). Uwarunkowania. Przejawy. Konsekwencje (Kraków 2008).

31 Wanda Dróżka, Pokolenia nauczycieli (Kielce: Wydawnictwo Naukowe WSP 1993); także Komitet Ekspertów, 169. 
do obowiązującego wówczas podręcznika pedagogiki, można stwierdzić, że o naukowym charakterze pedagogiki socjalistycznej miała decydować jej filozoficzna (ideologiczna) i metodologiczna podstawa. Za filozoficzną podstawę jej konstruowania uznano filozofię materializmu dialektycznego i historycznego. Praktycznie odwoływano się jednak do twierdzeń sformułowanych w tzw. MELS-ie ${ }^{32}$.

Ta doktryna, nie spełniająca pod żadnym względem wymagań jakiejkolwiek filozofii ani światopoglądu, zawierała również założenia i postulaty dotyczące obowiązującego poglądu na świat oraz budowania nauki w określonym paradygmacie nauki przyjętym w ZSRR.

Odwołując się do podstawowych dzieł, w których odnajdujemy koncepcję naukowej pedagogiki socjalistycznej, obowiązującej w Polsce począwszy od lat siedemdziesiątych XX wieku, możemy powiedzieć, że nazwa „naukowa pedagogika socjalistyczna" wprowadzała i nadal wprowadza w błąd, ponieważ najpierw nie była to jakakolwiek pedagogika, lecz najwyżej pedagogia, rozumiana jako paradygmat edukacyjny wyrażony i opisany $\mathrm{w}$ formie określonej doktryny pedagogicznej, a dowodzą tego także słowa twórcy naukowej pedagogiki socjalistycznej (pedagogii wychowania socjalistycznego) wypowiedziane w czasie Partyjnej Narady Pedagogów w 1973 roku ${ }^{33}$.

Oto one:

[...] musimy się dzisiaj zdobyć na pedagogikę ideowo zaangażowaną i uprawianą partyjnie, z partyjną odpowiedzialnością, przy wiodącym udziale partyjnych pedagogów. Dzisiaj właśnie pedagogowie partyjni stanowią siłę w naukach pedagogicznych i stać nas na to, abyśmy rzeczywiście mogli w całym tego słowa znaczeniu partyjną pedagogikę uprawiać"34.

Naukowa pedagogika socjalistyczna jest $\mathrm{w}$ istocie jedynie jakąś pedagogią (zwerbalizowaną $\mathrm{w}$ formie doktryny pedagogicznej, mającej swojego autora i określoną strukturę), której cele zostały wyprowadzone $\mathrm{z}$ „postępowej ideologii społecznej” (ideologii marksistowskiej), a opis oddziaływań wychowawczych służących realizacji tych celów uzasadnia je teoriami naukowymi (głównie opierając się na teoriach psychologicznych) i stanowi treść "teorii wychowania socjalistycznego". W moim przekonaniu nie można też takiej doktryny nazywać pedagogiką instrumentalną, lecz raczej była to ukierunkowana na wychowanie i edukację ideologia partyjna. Natomiast opis praktyki badawczej, służącej wytwarzaniu legitymizowanej wiedzy i dyrektyw praktycznego działania wyznaczała przyjęta specyficzna metodologia badań i wytwarzania wiedzy, uznawanej

32 Chodzi o ideologię będącą sumą poglądów Marksa, Engelsa, Lenina i Stalina.

33 Heliodor Muszyński, „Dyskusja - Partyjna Narada Pedagogów KNP PAN (3/4 grudnia 1973)". Kwartalnik Pedagogiczny 2 (1974): 64.

34 Chodzi o obowiązujący przez wiele lat podręcznik: Zarys pedagogiki, t. 1, red. Bogdan Suchodolski (Warszawa: Państwowe Wydawnictwo Naukowe 1962), wyd. II zmienione. 
według jej kryteriów za naukową. Obowiązywała zwłaszcza ta przedstawiona $\mathrm{w}$ dziele Wstęp do metodologii pedagogiki autorstwa Heliodora Muszyńskiego z 1970 roku $^{35}$.

Naukowa pedagogika socjalistyczna została sprowadzona do doktryny wychowania socjalistycznego, co pozwoliło na zawłaszczenie całego obszaru badań pedagogicznych. Skutkowało to tym, że odtąd prace projektujące skuteczne realizacje założonych celów wychowania socjalistycznego miały zielone światło $\mathrm{w}$ instytucjach promowania i popularyzowania badań oraz dostęp do środków finansowych na realizację tego typu badań, których efektem miały być projekty gwarantujące wyższą skuteczność w osiąganiu pożądanych efektów edukacjii ${ }^{36}$. Autorzy tych projektów badawczych i inicjatyw wydawniczych, wiernie realizując technikę wspomnianej wyżej tzw. now omowy ${ }^{37}$, posługiwali się w tym wypadku następującymi słowami-kluczami: „doskonalenie”, „modernizacja”, „służenie socjalistycznej praktyce”, „wdrażanie postępowej myśli”, „wdrażanie założonych celów wychowania socjalistycznego”, „realizacja uchwał i dyrektyw przewodniej sily narodu" 38 .

Świadomość wspólnoty złudzeń reformatorów oświaty i ich ekspertów (szczególnie pedagogów legitymujących się stopniami i tytułami naukowymi) dojrzewała jednak bardzo wolno. Pedagogia wychowania socjalistycznego, która zdominowała polską pedagogikę w latach siedemdziesiątych XX wieku, była tym trudniejsza do rozpoznania jako błędna, gdyż wpisywała się w ogólniejszy nurt myślenia o edukacji właściwy pedagogice empirycznej, która była kontynuacją pozytywistycznego modelu wytwarzania wiedzy naukowej, a w związku z tym wystarczyło tylko odpowiednio ustawiać akcenty propagandowe w związku z dążeniem do "naukowości”, aby tego rodzaju błędne teorie uwiarygadniać wobec ogółu społeczeństwa.

Chociaż mówi się o tym, że dopiero na przełomie lat osiemdziesiątych i dziewięćdziesiątych XX wieku zaczął pojawiać się zbiorowy namysł nad tożsamością polskiej pedagogiki, statusem myślenia o edukacji, wiedzą o edukacji, kształceniu i pedagogice, to jednak nawet w tym okresie pedagogika była dyscypliną, której odmawiano i w niektórych wypadkach ciągle jeszcze odmawia się jej własnego profilu i ciągle jest sprowadzana do spełniania wymagań, jakie rzekomo spełniają inne dyscypliny. Słusznie zatem wskazuje się, że tzw. rzekomy spór o definicję

35 Heliodor Muszyński, Wstęp do metodologii pedagogiki (Warszawa: Państwowe Wydawnictwo Naukowe 1970).

36 Zob. Hejnicka-Bezwińska, Praktyka edukacyjna w warunkach zmiany kulturowej, 325nn.

37 Wiązać ją należy z aspiracjami Stalina nazywanego zarazem „twórcą języka” i stanowiącego nowe kategorie do nazywania aktualnie doświadczanej rzeczywistości lub też jej stygmatyzacji zwłaszcza z użyciem negatywnych określeń dla jej dyskwalifikacji, natomiast pozytywnych dla ukazania jej np. postępowości oraz potrzeby jej wdrażania.

${ }_{38}$ Zob. także Hejnicka-Bezwińska, Praktyka edukacyjna w warunkach zmiany kulturowej, $240 \mathrm{nn}$. 
nauki okazuje się faktycznie sporem o strukturę dystrybucji kapitału, jakim jest autorytet dominującego sposobu jej uprawiania ${ }^{39}$.

\section{Pedagodzy z marginesu}

Należy też wyraźnie stwierdzić, że pedagodzy i pedagogika w omawianym okresie, tkwiący w głównym nurcie pedagogiki akademickiej znaczonym przez dominację tzw. „naukowej pedagogiki socjalistycznej/komunistycznej” ${ }^{40}$, w wielu wypadkach zostali „zauroczeni i uwiedzeni” przez wspomnianą pedagogikę socjalistyczną. Nie zabrakło jednak i takich, którzy potrafili zachować wierność mistrzom okresu swojej młodości i humanistycznej tradycji pedagogiki okresu międzywojennego. Przypisać to można szczęściu lub odziedziczonemu kapitałowi kulturowemu, a więc ludziom i instytucjom, a jedną z nich był w Polsce Katolicki Uniwersytet Lubelski, jego profesorowie, czy też w ogóle Kościół katolicki i inni bardziej odważni profesorowie i przedstawiciele pedagogiki ${ }^{41}$. W tym okresie samo studiowanie na kierunku pedagogika wiązało się z szeregiem trudności, które wzrosły zwłaszcza po umocnieniu się nowej ideologii. Na mocy rozporządzenia Ministerstwa Szkolnictwa Wyższego z 29 czerwca 1953 roku przejściowo zawieszono rekrutację na pierwszy rok studiów pedagogicznych w roku akademickim 1953/1954. Brak rekrutacji na pedagogikę doprowadził do jej powolnej likwidacji, m.in. na KUL-u.

Zlikwidowanie decyzją administracyjną władz państwowych studiów pedagogicznych spowodowało, że pedagogika zyskiwała często status międzywydziałowej katedry usługowej, świadczącej zajęcia dla przygotowujących się do zawodu nauczyciela studentów innych kierunków - głównie humanistycznych ${ }^{42}$.

Tak też na KUL-u w 1956 roku, wraz z odejściem ostatniego rocznika studentów pedagogiki, działalność Sekcji Pedagogicznej została zawieszona na całe ćwierćwiecze (aż do 1981 roku), powodując faktyczne jej przekształcenie się w okresie 1956-1981 w ogólnouniwersytecką agendę międzywydziałową o charakterze usługowym $\mathrm{w}$ zakresie przygotowania pedagogicznego dla studentów istniejących kierunków. Tego rodzaju agenda służyła zwłaszcza pedagogizacji studentów przygotowujących się do zawodu nauczyciela, m.in. gwarantując

39 Zbigniew Kwieciński, Wspólnota złudzeń reformatorów oświaty i ich ekspertów, reprint referatu wygłoszonego na konferencji naukowej nt. Badania oświatowe a polityka oświatowa, która odbyła się w Warszawie, 16-17 grudnia 1987 roku.

40 Nie jest to epitet; tak ją nazwali jej twórcy, zwolennicy i kontynuatorzy. Jej rekonstrukcje i dekonstrukcje są dostępne w pracach naukowych polskich pedagogów.

${ }_{41}$ Zob. Janusz Mariański, „Wydział Nauk Społecznych”, w: Księga pamiątkowa w 75-lecie Katolickiego Uniwersytetu Lubelskiego. Wkład w kulture polska w latach 1968-1993, red. Marian Rusecki (Lublin: Redakcja Wydawnictw KUL 1994), 344nn.

42 Zob. tamże. 
przygotowanie też przyszłych duszpasterzy i katechetek (na Wydziale Teologii). Również na Wydziale Nauk Humanistycznych KUL, w ramach przygotowania do zawodu nauczycielskiego, realizowano wykład z pedagogiki i dydaktyki dla studentów trzeciego roku studiów; zresztą analogiczna sytuacja występowała na wspomnianym Wydziale Teologii KUL, a zwłaszcza w odniesieniu do kandydatów do kapłaństwa - studentów Wydziału Teologii.

Chociaż było wielu prawdziwych bohaterów niezłomnych, jeśli chodzi o postawę wierności pedagogice, do których zaliczam m.in. prof. B. Nawroczyńskiego, moją uwagę skupiam na takich środowiskach jak: Katolickiego Uniwersytetu Lubelskiego oraz Akademii Teologii Katolickiej, czy też Papieskich Wydziałach Teologicznych w Krakowie, w Warszawie, we Wrocławiu i Poznaniu. W tych środowiskach funkcjonujący profesorowie - przedstawiciele katolickiej, czy też personalistycznej myśli pedagogicznej stanowili ważny punkt odniesienia dla polskiej myśli pedagogicznej.

Do takich osób zaliczam zwłaszcza prof. Stefana Kunowskiego (1909-1977) i ks. prof. Piotra Porębę (1908-1991) - funkcjonujących w ramach środowiska Katolickiego Uniwersytetu Lubelskiego, ale także katechetyków - zwłaszcza ks. prof. Mieczysława Majewskiego (1928-1999) ${ }^{43}$.

W związku z tym, że Stefan Kunowski jest bardziej znany, pominę obecnie bliższą prezentację jego sylwetki i jego funkcjonowania w zakresie uprawiania pedagogiki, przedstawię natomiast sylwetkę ks. prof. Piotra Poręby, zwłaszcza od roku 1942, gdy został uwięziony przez Gestapo za udział w tajnym nauczaniu, a następnie ukrywając się przed Niemcami, pracował w parafii Łososina Górna; po wojnie w latach 1946-1951 był katechetą w gimnazjum i kierownikiem internatu dla młodzieży męskiej w Grybowie; następnie w latach 1947-1950 studiował pedagogikę na Uniwersytecie Jagiellońskim w Krakowie, gdzie uzyskał tytuł magistra na podstawie pracy pt. Pedagogika Jana Ochorowicza. W 1950 roku został oskarżony o przynależność do Armii Krajowej, dlatego musiał ukrywać się do 1955, kiedy został uwolniony od zarzutu; w latach 1956-1963 pracował jako katecheta szkół średnich w Sędziszowie Małopolskim; w 1960 obronił na Uniwersytecie Warszawskim pracę doktorską pt. Pedagogika Jana Władysława Dawida na tle epoki i uzyskał tytuł doktora nauk humanistycznych w zakresie pedagogiki ${ }^{44}$.

W środowisku ATK na uwagę zasługuje zwłaszcza ks. prof. Janusz Tarnowski (1919-2012). W 1950 roku uzyskał stopień magistra filozofii w zakresie psychologii na Katolickim Uniwersytecie Lubelskim. W 1962 roku został dopuszczony do promocji doktorskiej na KUL. Promotorem przewodu był ks. prof. dr Józef Pastuszka; tytuł pracy: Typologia Heymansa-Le Senne'a - studium psychologiczne.

43 Zob. Jan Ziółek, „Katolicki Uniwersytet Lubelski w latach 1944-1992”, w: Księga pamiątkowa w 75-lecie Katolickiego Uniwersytetu Lubelskiego, 31-55.

44 Zob. Ksiegga pamiątkowa w 75-lecie Katolickiego Uniwersytetu Lubelskiego, 228-233. 
Wykładał pedagogikę na ATK. W 1972 roku uchwałą Rady Wydziału Teologicznego ATK został mu nadany stopień doktora habilitowanego za rozprawę pt.: Problem chrześcijańskiej pedagogiki egzystencjalnej. Dopiero w 1980 roku stopień ten został potwierdzony przez Centralną Komisję Kwalifikacyjną. W 1987 roku otrzymał tytuł profesora nadzwyczajnego nauk humanistycznych, został członkiem Komitetu Nauk Pedagogicznych przy PAN, Polskiego Komitetu Korczakowskiego, również Międzynarodowego Stowarzyszenia Studium Charakteru i Osobowości z siedzibą w Paryżu, a także członkiem Międzynarodowego Biura Katolickiego do spraw dziecka $\mathrm{z}$ siedzibą w Genewie. Zorganizował ośrodek duszpasterski skupiający grupy młodzieżowe i dziecięce, z którymi prowadził dialog pedagogiczny opisany w publikacjach książkowych. Ks. Tarnowski jest twórcą pedagogiki personalno-egzystencjalnej ${ }^{45}$.

Do tej grupy, którą Robert Kwaśnica nazywa „pedagogami z marginesu”, zaliczam także katechetyków funkcjonujących najczęściej na wydziałach filozofii, ale też socjologów (np. Jana Krucinę, Czesława Strzeszewskiego), czy również psychologów ukierunkowanych na psychologię osobowości bądź psychologię małego dziecka czy psychologię religii.

$\mathrm{W}$ analizie ich sytuacji związanej z uprawianiem pedagogiki zwracam uwage na następujące fakty: 1) Gdzie i jak publikowali?; 2) Jak się habilitowali?; 3) Jak funkcjonowali w zakresie kształcenia młodych pracowników nauki?

Oczywiście, każde z tych pytań wymagałoby odrębnego obszernego opracowania, a każda sytuacja scharakteryzowania w jej kontekstach i uwarunkowaniach. Mam też nadzieję, że zwłaszcza cenna inicjatywa Seminarium, w której uczestniczymy, i powołania czasopisma związanego z historią polskiej myśli pedagogicznej będzie służyła tego rodzaju opracowaniom i badaniom. Ograniczę się obecnie do krótkiego scharakteryzowania wymienionych aspektów w oparciu o konkretnie wybrane przykłady, postępując w podanej wyżej kolejności:

Ad. 1. Gdzie i jak publikowali?

Pedagodzy z marginesu nie mogli zaistnieć w wiodących czasopismach pedagogicznych ówczesnego czasu ze względu na cenzurę, która stwarzała pozory kontrolowania wszystkiego w najmniejszych szczegółach. Oczywiście i na szczęście były to tylko pozory, a każdy, kto doświadczył chociaż pewnego okresu życia w tamtym systemie, przy pewnej kreatywności osobistej zawsze znalazł sobie sposoby pozwalające na wyrażenie także swojego przynajmniej biernego oporu czym oczywiście doprowadzał do irytacji zwłaszcza tych, którzy uwierzyli propagandzie, że kontrolują wszystko.

Tego rodzaju postawy sprzeciwu i kontestacji nie były obce pedagogom marginesu. Wprawdzie ich artykuły nie ukazywały się na łamach sztandarowych

45 Wiesława Buczek, „Pedagogika personalno-egzystencjalna ks. Janusza Tarnowskiego. Dialog wychowawczy jako propozycja metody wychowania we współczesnej rodzinie, szkole, społeczeństwie”. Polska Myśl Pedagogiczna 3 (2017): 175-191. 
czasopism ówczesnej pedagogiki, ale za to towarzyszyło im poczucie szczególnej godności i świadomość własnej wartości jako pedagogów zachowujących swoją wolność i podmiotowość, które niewątpliwie należy wiązać z tymi ideami i wartościami, jakie przyświecały żołnierzom wyklętym. Byli oni też bardzo poszukiwani i cenieni w szeregu czasopism i publikacji zwłaszcza tzw. drugiego (nieformalnego) obiegu, ale też inicjowali bardzo ceniony dzisiaj dialog interdyscyplinarny na łamach czasopism właściwych dla innych dyscyplin, np. teologii czy historii itd. W środowisku KUL w Lublinie stosunkowo większą autonomią cieszyły się zwłaszcza czasopisma teologiczne, które dla cenzorów ideologii marksistowskiej były mało zrozumiałe i raczej lekceważone przez władzę komunistyczną. W tych zatem czasopismach (teologiczno-pastoralnych i katechetycznych), publikowali pedagodzy środowiska KUL i wielu katolickich ośrodków naukowych z terenu całego kraju.

Warto wspomnieć także o powstaniu m.in. na Wydziale Teologii KUL nowych struktur organizacyjnych, które stwarzały możliwość reprezentowania pedagogicznego stanowiska i czyniły wychowanie przedmiotem swoich analiz. Warto zwrócić uwagę chociażby na katedry takie, jak prowadzona przez ks. prof. Czesława S. Bartnika najpierw Katedra Teologii Historii, a następnie Katedra Teologii Rzeczywistości Ziemskich. Tego rodzaju katedry na Wydziale Teologii stwarzały okazję do podejmowania również zagadnień związanych z wychowaniem, należącym także do badanych w tej katedrze rzeczywistości ziemskich. Pewną pomocą były także pastoralne wskazania Soboru Watykańskiego II i poszukiwania w środowiskach katolickich także wymiaru pedagogicznego i edukacyjnego w działalności Kościoła. Na przykład bardzo liczne publikacje Stefana Kunowskiego wychodziły w „Rocznikach Teologiczno-Kanonicznych”, ale również w czasopismach historycznych, co niewątpliwie doprowadziło do zbliżenia między pedagogiką a teologią i co zaowocowało pedagogizacją katechetyki oraz wzrostem zainteresowania pedagogów pedagogiką chrześcijańskąa ${ }^{46}$ Warto też zauważyć, że nawet w tego rodzaju mrocznych czasach zdarzały się momenty tzw. o dwilży, gdy udawało się wspomnianemu autorowi czy wielu innym publikować (oczywiście po licznych interwencjach cenzury) w jakimś czasopiśmie o szerszym zasięgu;

Ad. 2. Jak się habilitowali?

Poza publikowaniem ważnym obszarem aktywności uczonych jest osiąganie kolejnych stopni naukowych czy tytułu. Takie cele stawiali sobie także pedagodzy z marginesu, w czym napotykali wiele trudności, które mogły wyglądać na niemożliwe do przezwyciężenia. Mam na uwadze taki moment w życiorysie Stefana Kunowskiego, czy ks. Józefa Wilka (1937-2003).

46 Wyrazem tego zainteresowania jest dość dynamiczny obecny rozwój i funkcjonowanie Zespołu Pedagogiki Chrześcijańskiej działającego pod Patronatem Komitetu Nauk Pedagogicznych PAN od 2004 roku. 
Ks. Józef Wilk w roku 1976 obronił doktorat z teologii pastoralnej. Habilitował się w roku 1988, na podstawie rozprawy: Znaczenie pierwszych doświadczeń dla religijnego wychowania małego dziecka $w$ rodzinie ${ }^{47}$. Chociaż jego dorobek habilitacyjny recenzowali pedagodzy, w tym m.in. prof. Stefan Wołoszyn, to jednak fakt, że kolokwium odbyło się na Wydziale Teologii KUL, sprawiał, że dyplom i formalne przypisanie zostawało przy teologii. Artykuły ks. Józefa Wilka ukazywały się przeważnie na łamach „Roczników Teologicznych KUL” i „Roczników Teologiczno-Kanonicznych KUL” czy czasopism pastoralnych - jak np. „Ateneum Kapłańskie". Publikował też $\mathrm{w}$ innych specjalistycznych periodykach pedagogiczno-wychowawczych, w tym wydawanych przez zgromadzenie salezjańskie, którego był członkiem ${ }^{48}$. Jego sytuacja odsłania pewien mechanizm istniejącej współpracy z pedagogami głównego nurtu, stwarzający możliwości osiągania stopni także dla tych z marginesu. Odsłania się także fakt funkcjonowania pewnej grupy pedagogów głównego nurtu, którzy tkwiąc w strukturach ówczesnych uwarunkowań uprawiania pedagogiki, potrafili się zdobyć na odwagę respektowania nade wszystko naukowych kryteriów i potrzeb naukowych w ramach swoich opinii i recenzji;

Ad. 3. Jak funkcjonowali pedagodzy $\mathrm{z}$ marginesu $\mathrm{w}$ kształceniu młodych pracowników nauki?

Wszyscy pedagodzy, zarówno ci głównego nurtu, jak też ci z marginesu w okresach całkowitego wykluczania pedagogiki jako kierunku studiów, najczęściej prowadzili zajęcia usługowe dla studentów innych kierunków w ramach pedagogizacji i realizacji przygotowania pedagogicznego. Na Katolickim Uniwersytecie Lubelskim prowadzone były zajęcia z pedagogiki na Wydziale Humanistycznym oraz na Wydziale Teologii - w tym zwłaszcza dla kandydatów do kapłaństwa. Takie zajęcia przez długi czas prowadził Stefan Kunowski w Lubelskim Seminarium Duchownym. Tego rodzaju wykładowcy nie mogli być promotorami prac dyplomowych bezpośrednio z pedagogiki, funkcjonowali natomiast jako świadczący usługową działalność na innych kierunkach, gdzie sporadycznie doprowadzali też do doktoryzowania się swoich doktorantów (np. z psychologii wychowania $)^{49}$.

Stawiane pedagogom tego rodzaju trudności i ograniczenia miały też swoje jeszcze inne pozytywne znaczenie - uświadamiały bowiem lęk i poczucie zagrożenia, jakie towarzyszyło przedstawicielom nowego porządku, skoro słowo pisane czy mówione rodziło aż tak wielkie obawy.

47 Józef Wilk, ks., Znaczenie pierwszych doświadczeń dla religijnego wychowania małego dziecka w rodzinie (Lublin: Redakcja Wydawnictw KUL 1987).

48 Zob. Robert Bieleń, „Salezjanin-Profesor w służbie rodziny. Biografia Ks. Prof. dra hab. Józefa Wilka sdb (1937-2003)", w: Wybrane zagadnienia teorii i praktyki pedagogiki rodziny, red. Barbara Kiereś, Marian Nowak, Danuta Opozda, (Lublin: Wydawnictwo KUL 2006), 17-23.

49 Zob. Mariański, Wydział Nauk Społecznych, 344nn. 
Pokazała to wydatnie transformacja ustrojowa, powodując, że ten właśnie tzw. główny nurt nazwany „naukową pedagogiką socjalistyczną” okazał się „wydmuszką", do której prawie nikt nie chciał się już przyznawać po roku 1989. Zmiana ustrojowa, jak zauważyła prof. Teresa Hejnicka-Bezwińska w tekście swojej laudacji z okazji nadania godności doktora honoris causa prof. Bogusławowi Śliwerskiemu, oznaczała dla humanistów z jednej strony utratę dotychczasowych punktów oparcia o charakterze ideologicznym, a z drugiej strony szerokie otwarcie kulturowe. Tym samym dokonało się swoiste przesunięcie takich osób i środowisk $\mathrm{z}$ marginesu pedagogiki do jej centrum, związane nie tylko z tym, że pojawiły się nowe i lepsze możliwości realizowania zainteresowań badawczych, ale pojawiło się również zobowiązanie intelektualne, obywatelskie i moralne, najpełniej wyrażone w temacie I Zjazdu Pedagogicznego, którego uczestnicy obradowali w 1993 roku na temat: Ewolucji tożsamości pedagogikijo. To zobowiązanie można nazwać krótko i wprost - zobowiązaniem do uczestniczenia w Wielkiej Zmianie.

Streszczenie: Autor poddaje bliższej analizie sytuację pedagogiki i jej uprawiania w Polsce w okresie PRL-u, w którym obok pedagogów głównego nurtu spotykamy pewną grupę pedagogów, których Robert Kwaśnica określił jako „pedagogów marginesu”. Tym właśnie pedagogom zostaje poświęcona szczególna uwaga. Charakteryzując tło historyczno-społecznoideowe wymienionego okresu, autor poszukuje odpowiedzi na pytanie o proces dojrzewania świadomości złudzeń reformatorów oświaty i ich ekspertów, wskazując na propagandowe wpisywanie się tej ideologii w pozory kontynuowania pozytywistycznego modelu wytwarzania wiedzy naukowej. Obok wielu, którzy zostali „zauroczeni i uwiedzeni” przez pedagogikę socjalistyczną, nie zabrakło tych, którzy potrafili zachować wierność mistrzom okresu swojej młodości i humanistycznej tradycji pedagogiki okresu międzywojennego.

Przemiany, jakie zaczęly się dokonywać po 1989 roku, zaowocowały swoistym przesunięciem „pedagogów z marginesu” (z peryferii) do centrum myśli pedagogicznej i szczególnym zobowiązaniem intelektualnym, obywatelskim i moralnym do uczestniczenia w Wielkiej Zmianie.

Słowa kluczowe: pedagogika, pedagodzy z marginesu, pedagogika socjalistyczna/komunistyczna, pedagogika humanistyczna, ideologia

50 Zapis tego wydarzenia znajduje się w pracy: Ewolucja tożsamości pedagogiki, red. Henryka Kwiatkowska (Warszawa: Polskie Towarzystwo Pedagogiczne 1994). Sekcję III zorganizował i prowadził prof. Śliwerski. Zapis tego wydarzenia mamy w pracy: Kontestacje pedagogiczne. Materiały III Sekcji Zjazdu Pedagogów, red. Bogusław Śliwerski (Kraków: Oficyna Wydawnicza „Impuls” 1993). 


\section{Bibliografia}

Bieleń, Robert. „Salezjanin-Profesor w służbie rodziny. Biografia Ks. Prof. dra hab. Józefa Wilka sdb (1937-2003)". W: Wybrane zagadnienia teorii i praktyki pedagogiki rodziny, red. Barbara Kiereś, Marian Nowak, Danuta Opozda,. 17-23. Lublin: Wydawnictwo KUL, 2006

Buczek, Wiesława. „Pedagogika personalno-egzystencjalna ks. Janusza Tarnowskiego. Dialog wychowawczy jako propozycja metody wychowania we współczesnej rodzinie, szkole, społeczeństwie”. Polska Myśl Pedagogiczna 3 (2017): 175-191.

Draus, Jan, Terlecki, Ryszard. Historia wychowania, t. 2: Wiek XIX i XX. Kraków: Wydawnictwo WAM - WSFP „Ignatianum”, 2005.

Dróżka, Wanda. Pokolenia nauczycieli. Kielce: Wydawnictwo Naukowe WSP, 1993.

Górski, Karol. Wychowanie personalistyczne. Poznań: Drukarnia Diecezjalna we Włocławku, 1936.

Hejnicka-Bezwińska, Teresa, W poszukiwaniu tożsamości pedagogiki. Świadomość teoretyczno-metodologiczna współczesnej pedagogiki polskiej (Geneza i stan). Bydgoszcz: WSP, 1989.

Hejnicka-Bezwińska, Teresa. Paradygmat pedagogiki instrumentalnej w Polsce (Skutki jego dominowania $w$ badaniach pedagogicznych $i$ kształceniu pedagogów). W: Ku pedagogii pogranicza, red. Zbigniew Kwieciński, Lech Witkowski, 158-175. Toruń: Uniwersytet Mikołaja Kopernika, 1990.

Hejnicka-Bezwińska, Teresa. Praktyka edukacyjna w warunkach zmiany kulturowej. Warszawa: Wydawnictwo Naukowe PWN, 2015.

Historia wychowania. Wiek XX, t. I-II, red. Józef Miąso. Warszawa: Państwowe Wydawnictwo Naukowe, 1981.

Katolicka myśl wychowawcza. Pamiętnik II. Studium Katolickiego w Wilnie w dniach 28.VIII 1.IX. 1936 r., w serii Studia Katolickie, red. ks. dr Stanisłaa Bross. Poznań: Nakładem Naczelnego Instytutu Akcji Katolickiej, 1937.

Komitet Ekspertów dla Opracowania Raportu o Stanie Oświaty w PRL, red Jan Szczepański, Warszawa, 1973.

Kontestacje pedagogiczne. Materiały III Sekcji Zjazdu Pedagogów, red. Bogusław Śliwerski. Kraków: Oficyna Wydawnicza „Impuls”, 1993.

Księga pamiątkowa w 75-lecie Katolickiego Uniwersytetu Lubelskiego. Wkład w kulturę polską w latach 1968-1993, red. Marian Rusecki. Lublin: Redakcja Wydawnictw KUL, 1994.

Kunowski, Stefan. „Polscy teoretycy wychowania”. W: Wkład Polaków do kultury świata, red. Mieczysław A. Krąpiec, Piotr Taras, Jan Turowski, 243-256. Lublin: Towarzystwo Naukowe KUL, 1976.

Kwaśnica, Robert. „O dwóch wersjach pytania o przedrozumienie. Do pedagogiki naukowej i pedagogów z marginesu”. W: Pytanie - dialog - wychowanie, red. Joanna Rutkowiak. Warszawa: Wydawnictwo Naukowe PWN, 1992.

Kwieciński Zbigniew. Konieczność - niepokój - nadzieja. Problemy oświaty w latach siedemdziesiatych. Warszawa: Ludowa Spółdzielnia Wydawnicza, 1982.

Mariański, Janusz. „Wydział Nauk Społecznych”. W: Księga pamiątkowa w 75-lecie Katolickiego Uniwersytetu Lubelskiego. Wkład w kulture polska w latach 1968-1993, red. Marian Rusecki. Lublin: Redakcja Wydawnictw KUL, 1994.

Muszyński, Heliodor. Wstęp do metodologii pedagogiki. Warszawa: Państwowe Wydawnictwo Naukowe, 1970.

Muszyński, Heliodor. „Dyskusja - Partyjna Narada Pedagogów KNP PAN (3/4 grudnia 1973)”. Kwartalnik Pedagogiczny 2 (1974): 64-76. 
Okoń, Wincenty. „Sytuacja i perspektywy rozwoju pedagogiki w Polsce Ludowej”. W: Stan i perspektywy rozwoju nauk pedagogicznych, red. Wincenty Okoń, 35-39. Warszawa: Państwowe Wydawnictwo Naukowe, 1976.

Orczyk, Adam, ks. Zarys historii szkolnictwa i myśli pedagogicznej. Warszawa: Wydawnictwo Akademickie „Żak”, 2008.

Raport o stanie oświaty w PRL. Warszawa: Państwowe Wydawnictwo Naukowe, 1973.

Wilk, Józef, ks. Znaczenie pierwszych doświadczeń dla religijnego wychowania małego dziecka w rodzinie. Lublin: Redakcja Wydawnictw KUL, 1987.

Wojnar, Irena. „Bogdan Suchodolski”. W: Myśliciele o wychowaniu, t. 2, 391-397. Warszawa: Oficyna Wydawnicza BGW, 2001.

Wroczyński, Ryszard. Dzieje oświaty polskiej 1795-1945. Warszawa: Wydawnictwo „Żak”, 1996.

Zarys pedagogiki, t. 1-2, red. Bogdan Suchodolski. Warszawa: Państwowe Wydawnictwo Naukowe, 1962 (wyd. II zmienione).

Ziółek, Jan. „Katolicki Uniwersytet Lubelski w latach 1944-1992”. W: Ksiegga pamiątkowa w 75-lecie Katolickiego Uniwersytetu Lubelskiego. Wkład w kulturę polskq w latach 1968-1993, 31-55. Lublin: Redakcja Wydawnictw KUL, 1994. 